\title{
FAKTOR-FAKTOR YANG MEMPENGARUHI KEPATUHAN MEMBAYAR PAJAK BUMI DAN BANGUNAN PEDESAAN DAN PERKOTAAN
}

\author{
Khasan Setiaji ${ }^{1}$, Adibatun Nisak ${ }^{2}$ \\ Jurusan Pendidikan Ekonomi \\ Universitas Negeri Semarang \\ Semarang, Indonesia
}

e-mail: setiaji@mail.unnes.ac.id ${ }^{1}$, nisakadibatun@gmail.com²

\begin{abstract}
Abstrak
Pajak sangat berperan dalam menggerakkan roda perekonomian yang ada di Indonesia. Namun pada saat ini banyak wajib pajak yang melakukan tindakan penghindaran, pengelakan, dan pelalaian pajak yang pada akhirnya akan menyebabkan peneriman pajak negara akan berkurang. Tujuan penelitian ini adalah untuk mengetahui pengaruh motivasi, SPPT, pelayaan fiskus, dan kesadaran wajib pajak terhadap kepatuhan membayar pajak bumi dan bangunan pedesaan dan perkotaan di Desa Nolokerto baik secara simultan maupun secara parsial. Jenis penelitia ini digolongkan sebagai penelitian kuaintitatif. Populasi dalam peneitian ini adalah seluruh WP PBB P-2 di Desa Nolokerto. Penelitian ini menggunakan teknik pengambilan sampel dengan menggunakan teknik Propotional stratified random sampling. Teknik analisis data yang digunakan adalah regresi berganda. Hasil penelitian menunjukkan bahwa motivasi, SPPT, pelayanan fiskus, dan kesadaran wajib pajak berpengaruh positif dan signifikan terhadap kepatuhan membayar PBB P2 di Desa Nolokerto baik secara parsial maupun simultan. Saran dalam meningkatkan kepatuhan membayar PBB P-2, maka pemerintah harus meningkatkan motivasi wajib pajak untuk memenuhi kewajiban perpajakannya, meningkatkan keakuratan data pada SPPT dengan melakukan survey secara rutin; meningkatkan pelayanan perpajakan bumi dan bangunan P2 terhadap wajib pajak, dan meningkatkan kesadaran wajib pajak dengan mengadakan sosialisasi atau penyuluhan dan informasi perpajakan, menciptakan aparatur pemerintah yang bersih dan berwibawa.
\end{abstract}

Kata Kunci: Motivasi, SPPT, Prelayanan Fiskus, Kesadarran Wajib Pajak, Kepatuh

\begin{abstract}
Taxes are instrumental in driving the wheels of the economy in Indonesia. But at this time many taxpayers who do evasion, evasion, and tax negligence that will ultimately lead to the state tax revenue will be reduced. The purpose of this study is to determine the effect of motivation, SPPT, fiscal services, and taxpayer awareness of compliance pay taxes earth and rural and urban buildings in the village of Nolokerto either simultaneously or partially. This type of research is classified as quaintitative research. Population in this research is all WP PBB P-2 in Nolokerto Village. This research uses sampling technique by using technique of Propotional stratified random sampling. Data analysis technique used is multiple regression. The results showed that motivation, SPPT, fiscal services, and taxpayer awareness have a positive and significant effect on P-2 PBB pay compliance in Nolokerto Village either partially or simultaneously. Suggestion in increasing compliance to pay UN P-2, then the government should increase taxpayer motivation to fulfill its tax obligations, improve
\end{abstract}


data accuracy on SPPT by conducting routine survey; improve the tax services of earth and building P2 to taxpayers, and increase awareness of taxpayers by holding socialization or counseling and information taxation, creating a clean and authoritative government apparatus.

Keywords: Motivation, SPPT, Fiskus Service, Tax Payer Concern, Compliance

\section{PENDAHULUAN}

Salah satu sumber penerimaan negara adalah dari hasil pemungutan pajak. Sebagai salah satu penerimaan negara, pajak sangat diandalkan untuk pembiayaan pembangunan dan pengeluaran negara. Pajak adalah iuran rakyat kepada kas negara berdasarkan undang-undang (yang dapat dipaksakan) dengan tidak mendapat jasa timbal balik (kontraprestasi) yang langsung dapat ditunjukkan dan yang digunakan untuk membiayai pengeluaran umum (Soemitro dalam Resmi,2011). Dari definisi tersebut tergambar bahwa salah satu fungsi pajak, yaitu sebagai sumber penerimaan negara (fungsi budgeter). Pajak bumi dan bangunan adalah pajak yang dikenakan atas objek pajak bumi dan bangunan yang diatur pengenaannya berdasarkan Undang-Undang No. 12 tahun 1994 (Tjahjono dan Wahyudi,2005).

Pemerintah dalam pelaksanaan penarikan pajak bumi dan bangunan masih banyak mengalami kendala antara lain masih kurangnya kepatuhan masyarakat dalam membayar PBB P2. Seperti yang terjadi di Desa Nolokerto Kecamatan Kaliwungu. Berikut data mengenai target dan realisasi penerimaan PBB P-2 Kecamatan Kaliwungu tahun 2014, 2015, dan 2016.

Tabel 1. Realisasi Penerimaan PBB P-2 Kecamatan Kaliwungu

\begin{tabular}{|c|c|c|c|c|c|c|c|c|c|c|}
\hline \multirow[b]{2}{*}{ No } & \multirow[b]{2}{*}{ Desa /Kelurahan } & \multicolumn{2}{|c|}{ Realisasi 2014} & \multirow[b]{2}{*}{$\%$} & \multicolumn{2}{|c|}{ Realisasi 2015} & \multirow[b]{2}{*}{$\%$} & \multicolumn{2}{|c|}{ Realisasi 2016} & \multirow[b]{2}{*}{$\%$} \\
\hline & & $\begin{array}{l}\text { SPP } \\
T\end{array}$ & $\begin{array}{l}\text { Realisas } \\
\mathrm{i}\end{array}$ & & $\begin{array}{l}\text { SPP } \\
T\end{array}$ & $\begin{array}{l}\text { Realisas } \\
\text { i }\end{array}$ & & $\begin{array}{l}\text { SPP } \\
T\end{array}$ & $\begin{array}{l}\text { Realisas } \\
\text { i }\end{array}$ & \\
\hline A. & PERDESAAN & & & & & & & & & \\
\hline \multirow[t]{2}{*}{1.} & WONOREJO & 1.758 & 949 & 44,53 & 1.756 & 956 & 51,17 & 1.774 & 729 & 61,87 \\
\hline & JUMLAH A & 1.758 & 949 & 44,53 & 1.756 & 956 & 51,17 & 1.774 & 729 & 61,87 \\
\hline B. & PERKOTAAN & & & & & & & & & \\
\hline 2. & KUMPULREJO & 1.095 & 639 & 36,57 & 1.090 & 717 & 33,53 & 1.091 & 482 & 53,31 \\
\hline 3. & $\begin{array}{l}\text { KARANG } \\
\text { TENGAH }\end{array}$ & 1.373 & 1.077 & 42,07 & 1.417 & 920 & 50,22 & 1.435 & 1.047 & 35,91 \\
\hline 4. & SARIREJO & 2.540 & 606 & 76,63 & 2.624 & 813 & 74,62 & 2.854 & 973 & 72,35 \\
\hline 5. & KRAJANKULON & 2.470 & 1.036 & 53,41 & 2.461 & 988 & 57,99 & 2.461 & 1.003 & 58,71 \\
\hline 6. & KUTOHARJO & 3.278 & 1.579 & 56,90 & 3.236 & 1.315 & 67,60 & 3.246 & 1.319 & 61,57 \\
\hline 7. & NOLOKERTO & 3.304 & 1.525 & 83,36 & 3.303 & 1.427 & 43,38 & 3.335 & 1.586 & 25,86 \\
\hline 8. & SUMBEREJO & 3.170 & 1.477 & 63,70 & 3.202 & 1.475 & 62,20 & 3.238 & 1.613 & 62,06 \\
\hline \multirow[t]{3}{*}{9.} & MOROREJO & 2.795 & 1.319 & 76,17 & 2.734 & 1.623 & 73,39 & 2.738 & 1.948 & 65,80 \\
\hline & JUMLAH B & $\begin{array}{l}20.02 \\
5\end{array}$ & 9.258 & 72,23 & $\begin{array}{l}20.06 \\
7\end{array}$ & 9.278 & 55,99 & $\begin{array}{l}20.39 \\
8\end{array}$ & 9.935 & 46,39 \\
\hline & JUMLAH A + B & $\begin{array}{l}21.78 \\
3\end{array}$ & 10.207 & 70,93 & $\begin{array}{l}21.82 \\
3\end{array}$ & 10.234 & 55,76 & $\begin{array}{l}22.17 \\
2\end{array}$ & 10.980 & 47,14 \\
\hline
\end{tabular}


Berdasarkan tabel 1. dapat diketahui bahwa realisasi penerimaan PBB P-2 Desa Nolokerto dari tahun 2014 sampai tahun 2016 selalu menurun. Bahkan pada tahun 2016 hanya sebesar 25,86\% wajib pajak yang memenuhi kewajibannya untuk membayar pajak.

Salah satu cara untuk mengoptimalkan penerimaan PBB P-2 adalah dengan meningkatkan kepatuhan wajib pajak. Kepatuhan perpajakan dapat di definisikan sebagai suatu keadaan dimana wajib pajak memenuhi semua kewajiban perpajakannya (Nurmantu dalam Rahayu,2006). Menurut kamus umum bahasa Indonesia dalam Rahayu (2006:110) istilah kepatuhan berarti tunduk atau patuh pada ajaran atau aturan.Menurut Erard dan Feinstein yang di kutip oleh Chaizi Nasucha dan di kemukakan kembali oleh Rahayu (2006) pengertian kepatuhan wajib pajak adalah rasa bersalah dan rasa malu, persepsi wajib pajak atas kewajaran dan keadilan beban pajak yang mereka tanggung, dan pengaruh kepuasan terhadap pelayanan pemerintah.Menurut Nurmantu dalam Rahayu (2006) menyatakan bahwa kepatuhan perpajakan dapat didefinisikan sebagai suatu keadaan di mana wajib pajak memenuhi semua kewajiban perpajakan dan melaksanakan hak perpajakannya. Dari beberapa definisi tersebut dapat disimpulkan bahwa kepatuhan membayar pajak adalah wajib pajak yang taat dan memenuhi serta melaksanakan kewajiban perpajakan sesuai dengan ketentuan perundangundangan perpajakan.

Kepatuhan wajib pajak dipengaruhi oleh beberapa faktor, yaitu: kondisi sistem administrasi pajak suatu negara, pelayanan pada wajib pajak, penegakan hukum perpajaka, pemeriksaan pajak, dan tarif pajak (Devano dan Rahayu,2006). Faktor-faktor yang mempengaruhi kepatuhan membayar pajak diantaranya adalah motivasi.Hasil penelitian yang dilakukan oleh Husein (2012) dan Putri (2016) menyatakan bahwa motivasi berpengaruh secara signifikan terhadap kepatuhan membayar PBB P-2. Motivasi diartikan kekuatan, dorongan, kebutuhan, semangat, tekanan, atau mekanisme psikologi yang mendorong seseorang atau kelompok orang untuk mencapai prestasi tertentu sesuai dengan apa yang dikehendakinya (Danim,2012). Motivasi adalah keinginan untuk melakukan sesuatu dan menentukan kemampuan bertindak untuk memuaskan kebutuhan individu (Robbins,2002). Herzberg (1968) dalam Robbins (2002) mengemukakan sebuah teori yang disebut Motivation Hygiene Theory, teori ini mengungkapkan bahwa terdapat dua faktor yang mempengaruhi motivasi, yang pertama adalah faktor motivasional yang merupakan hal-hal yang sifatnya intrinsik atau bersumber dari dalam diri seseorang, sedangkan faktor kedua adalah faktor hygiene atau pemeliharaan yang merupakan faktor-faktor dengan sifat ekstrinsik yang bersumber dari luar diri individu yang turut menentukan perilaku seseorang dalam kehidupan seseorang. Begitu pula dalam hal perpajakan, terdapat faktor intrinsik dan ekstrinsik yang mempengaruhi motivasiwajib pajak dalam membayar pajak.Faktor lain yang diduga mempengaruhi kepatuhan membayar pajak bumi dan banguanan adalah surat pemberitahuan pajak terutang (SPPT) karena di dalamnya terdapat kebenaran pajak yang harus dibayarkan. SPPT adalah surat yang digunakan oleh direktorat jendaral pajak untuk memberitahukan besarnya pajak yang terutang kepada wajib pajak (Waluyo,2004).SPPT adalah surat keputusan kepala kantor pelayanan Pajak Bumi dan Bangunan mengenai pajak terutang yang harus dibayar dalam 1 tahun pajak (Suryarini dan Tarmuji,2009). Dalam Pasal 1 Angka 54 UU Nomor 28 Tahun 2009 Tentang Pajak Daerah dan Retribusi Daerah) dijelaskan bahwa, "Surat Pemberitahuan Pajak Terutang adalah surat yang digunakan untuk memberitahukan besarnya pajak bumi dan bangunan pedesaan dan perkotaan yang terutang kepada wajib pajak.Dari definisi tersebut dapat disimpulan bahwa SPPT adalah surat yang di keluarkan oleh 
Direktorat Jenderal Pajak Daerah yang digunakan untuk memberitahu jumlah pajak terutang yang dibayarkan wajib pajak sebelum jatuh tempo.SPPT dapat diterbitkan berdasarkan Surat Pemberitahuan Objek Pajak yang diterima oleh subyek pajak atau berdasarkan data yang ada di kantor pajak (Samudra,1995).Hasil penelitian yang dilakukan oleh Yusnidar (2015) dan Fauzi (2016), menyatakan bahwa SPPT berpengaruh signifikan terhadap kepatuhan membayar pajak bumi dan bangunan pedesaan dan perkotaan. Dalam wawancara langsung dengan wajib pajak memang mengeluhkan mengenai data yang ada dalam SPPT yang kurang akurat. Seperti nama dan alamat wajib pajak, sering kali masih dibebankan atas nama wajib pajak lama padahal sudah terjadi pengalihan, dan sudah dilaporkan, adanya objek pajak ganda. Hal ini disebabkan kelalaian petugas. Dan juga nama dan alamat wajib pajak seringkali terjadi kekeliruan data. Dari penjelasan tersebut SPPT dijadikan masalah dalam penelitian ini. Faktor lain yang diduga mempengaruhi kepatuhan membayar pajak bumi dan bangunan pedesaan dan perkotaan adalah pelayanan fiskus. Pelayanan adalah sutu proses bantuan kepada orang lain dengan cara-cara tertentu yang memerlukan kepekaan dan hubungan interpersonal agar tercipta kepuasan dan keberhasilan (Boediono,2003).Pelayanan adalah setiap tindakan atau perbuatan yang dapat ditawarkan oleh suatu pihak kepada pihak lain, yang pada dasarnya bersifat intangible (tidak berwujud fisik) dan tidak menghasilkan kepemilikan sesuatu (Alghifari,2015).Ada hubungan timbal balik antara kepatuhan membayar pajakdengan kinerja pemerintah, terutama yang menyangkut jasa pelayananpublik yang berkaitan langsung dengan kepentingan masyarakat.Kepatuhan masyarakat untuk membayar pajak dapat ditingkatkan apabilaseluruh aparat pemerintah meningkatkan dan memperbaiki mutupelayanannya. Hasil penelitian yang dilakukan Yusnidar (2015) menyebutkan bahwa kualitas pelayanan fiskus berpengaruh signifikan positif terhadap tingkat kepatuhan wajib pajak.

Menurut wawancara awal terhadap wajib pajak Desa Nolokerto fasilitas pendukung seperti ruang tunggu kurang memadai, dalam SPPT yang diberikan juga masih terdapat kesalahan administrasi perpajakan yang membuat masyarakat enggan untuk membayar pajak. Faktor lain yang di duga berpengaruh terhadap kepatuhan membayar pajak adalah kesadaran wajib pajak. kesadaran adalah suatu keadaan dimana wajib pajak dalam keadaan tahu, mengerti, dan tidak merasa dipaksa ataupun takut dalam melaksanakan kewajibannya, karena adanya nilai-nilai hukum dalam diri wajib pajak dan adanya pengetahuan bhwa perilaku tertentu diatur oleh hukum (Riono,2011).

Beberapa bentuk kesadaran membayar pajak yang mendorong wajib pajak untuk membayar pajak. Pertama, kesadaran bahwa pajak merupakan bentuk partisipasi dalam menunjang pembangunan negara. Dengan menyadari hal ini, wajib pajak mau membayar pajak karena merasa tidak dirugikan dari pemungutan pajak yang dilakukan. Kedua, kesadaran bahwa penundaan pembayaran pajak dan pengurangan beban pajak sangat merugikan negara. Wajib pajak mau membayar pajak karena memahami bahwa penundaan pembayaran pajak dan pengurangan beban pajak berdampak pada kurangnya sumber daya finansial yang dapat mengakibatkan terhambatnya pembangunan negara. Ketiga, kesadaran bahwa pajak ditetapkan dengan Undangundang dan dapat dipaksakan. Wajib pajak akan membayar karena pembayaran pajak disadari memiliki landasan hukum yang kuat dan merupakan kewajiban mutlak setiap warga negara.Kesadaran membayar pajak dapat timbul karena adanya pengetahun dan pemahaman wajib pajak mengenai perpajakan. Sehingga wajib pajak yang memiliki pendidikan semakin tinggi cenderung akan semakin patuh dalam 
membayar pajak karena mereka memiliki kesadaran yang tinggi akan pentingnya membayar pajak bumi dan buangunan.Hasil penelitian yang dilakukan oleh Junaidi (2013) dan Puspita (2016) menjelaskan bahwa kesadaran wajib pajak berpengaruh positif dan signifikan terhadap kepatuhan wajib pajak.

Kajian utama pada penelitian ini adalah teori artibusi yang dikemukankan oleh Fritz Heider, yaitu, bahwa bila individu-individu mengamati perilaku seseorang, maka mencoba untuk menentukan apakah itu disebabkan oleh faktor internal atau faktor eksternal (Robbin,2002). Relevansi dari teori artribusi dalam penelitian ini adalah bahwa seseorang dalam mementukan patuh atau tidak patuh dalam membayar pajak dipengaruhi oleh faktor internal dan faktor eksternal. Faktor internal tersebut adalah motivasi dan kesadaran wajib pajak, sedangkan faktor eksternal yang mempengaruhi kepayuhan membayar PBB P-2 adalah SPPT dan pelayanan fiskus.

Tujuan dari penelitian ini adalah untuk mengetahui dan menganalisis: (1) pengaruh motivasi, SPPT, pelayanan fiskus, kesadaran wajib pajak terhadap kepatuhan membayar PBB P-2 di desa Nolokerto, (2) pengaruh motivasi terhadap kepatuhan membayar PBB P-2 di desa Nolokerto, (3) pengaruh SPPT terhadap kepatuhan membayar PBB P-2 di desa Nolokerto, (4) pengaruh pelayanan fiskus terhadap kepatuhan membayar PBB P-2 di desa Nolokerto, (5) pengaruh kesadaran wajib pajak terhadap kepatuhan membayar PBB P-2 di desa Nolokerto.

\section{METODE}

Jenis penelitian yang dilakukan adalah jenis penelitian kuantitatif untuk mencari pengaruh anatar variabel bebas dan variabel terikat (Sugioyo,2015). Populasinya seluruh wajib pajak bumi dan bangunan yang berada Di Desa Nolokerto Kecamatan Kaliwungu yang berjumlah 3.335 wajib pajak bumi dan bangunan pedesaan dan perkotaan. Dari jumlah populasi tersebut maka dapat diketahui jumlah sampel berdasarkan rumus slovin (Prasetyo,2008) yaitu 98 WP PBB P-2

Teknik pengambilan sampel menggunakan teknik Proportionate stratified random sampling yaitu teknik pengambilan sampel yang dilakukan dengan membagi anggota populasi dalam beberapa sub kelompok yang disebut strata (tingkat pendidikan), lalu sampel dipilih dari masing-masing strata. Penarikan sampel ini digunakan untuk populasi yang mempunyai anggota atau unnsur yang tidak homogen (Suharyadi dan Purwanto,2009). Pengambilan datanya dilakukan secara random. Penentuan responden penelitian dengan melihat dari tingkat pendidikan wajib pajak. berikut tabel penentuan responden penelitian.

Tabel 2. Penentuan Responden Penelitian

\begin{tabular}{lllll}
\hline No & $\begin{array}{l}\text { Tingkat } \\
\text { pendidikan }\end{array}$ & Populasi & $\begin{array}{l}\text { Proportional } \\
\text { stratafied }\end{array}$ & Jumlahsampel \\
\hline 1. & SD & 126 & $(126: 781) \times 98$ & 16 \\
2. & SMP & 150 & $(150: 781) \times 98$ & 19 \\
3. & SMA & 367 & $(367: 781) \times 98$ & 45 \\
4. & Diploma & 72 & $(19: 781) \times 98$ & 9 \\
7. & Sarjana & 67 & $(59: 781) \times 98$ & 9 \\
\hline Jumlah & 781 & & 98 \\
\hline
\end{tabular}


Penelitian ini menggunakan lima variabel, yaitu empat variabel independen dan satu variabel dependen. Variabel dependen dalam penelitian ini adalah kepatuhan membayar pajak. Variabel ini diukur dengan menggunakan indikator menurut Rahayu (2010), yaitu: wajib pajak melakukan pembayaran tepat waktu, wajib pajak melakukan pembayaran tepat jumlah, wajib pajak tidak memiliki tunggakan pajak. Sedangkan variabel independen dalam penelitian ini adalah (1) motivasi. Variabel ini diukur dengan menggunakan indikator menurut Danim (2012) yaitu: kejujuran wajib pajak, hasrat untuk membayar pajak, dorongan dari aparat pajak, lingkungan kerja, teman , dan kerabat (2) SPPT dengan Indikator menurut Ronia (2011) yaitu: data wajib pajak pada SPPT, tempat pembayaran pajak yang tereta di SPPT, tanggal jatuh tempo, luas tanah pada SPPT, NJOP atas tanah pada SPPT, luas bangunan pada

\section{HASIL DAN PEMBAHASAN}

Dari data yang telah terumpul dan telah diuji asumsi klasik, diperoleh hasil bahwa data layak dianalisis dalam model
SPPT, NJOP atas bangunan pada SPPT (3) pelayanan fiskus dengan indikator dari variabel pelayanan fiskus menurut Parasuraman (1985) dalam Rahmayanty (2013) yaitu: tangibles (bukti fisik), realibity (keandalan), assurance (jminan), dan emphaty (empati) (4) kesadaran wajib pajak yang diukur dari indikator dari variabel kesadaran wajib pajak menurut Suryarini dan Tarmuji (2006) adalah: sebab kultural dan historis, kurangnya informasi, adanya kebocoran pada penarikan pajak, suasanan individu.

Metode pengumpulan data dengan menggunaakan angket atau kuisioner. Metode analisis data yang digunakan dalam penelitian ini adalah analisis regresi linier berganda untuk menguji hipotesis dengan melakukan uji secara simultan (uji F) dan uji secara parsial (uji t). Sebelum pengujian hipotesis, dilakukan pengujian kualitas data yang terdiri dari uji validitas dan reliabilitas data (Trihendradi,2013).

regresi. Berdasarkan hasil analisis regresi berganda maka hasil dapat dilihat pada Tabel 3.

Tabel 3. Hasil Analisis Regresi Linier Berganda

\begin{tabular}{|c|c|c|c|c|c|c|c|c|c|}
\hline \multicolumn{10}{|c|}{ Coefficients $^{a}$} \\
\hline \multirow{3}{*}{\multicolumn{2}{|c|}{ Model }} & \multirow{2}{*}{\multicolumn{2}{|c|}{$\begin{array}{l}\text { Unstandardized } \\
\text { Coefficients }\end{array}$}} & \multirow{2}{*}{\multicolumn{3}{|c|}{$\begin{array}{l}\text { Standardized } \\
\text { Coefficients }\end{array}$}} & \multirow[b]{3}{*}{ Sig. } & \multirow{2}{*}{\multicolumn{2}{|c|}{$\begin{array}{l}\text { Collinearity } \\
\text { Statistics }\end{array}$}} \\
\hline & & & & & & & & & \\
\hline & & $\mathrm{B}$ & Std. Error & Beta & & $\mathrm{T}$ & & Tolerance & VIF \\
\hline \multirow[t]{5}{*}{1} & (Constant) & 2,315 & 2,081 & & & 1,113 & ,269 & & \\
\hline & Motivasi & , 159 & ,068 & & ,242 & 2,332 & ,022 & ,431 & 2,322 \\
\hline & Sppt & ,258 & , 108 & & 199 & 2,391 & 019 & 674 & 1,484 \\
\hline & Pelayanan & ,133 & ,051 & & ,254 & 2,608 & 011 & ,489 & 2,047 \\
\hline & Kesadaran & 222 & ,101 & & 214 & 2,196 & ,031 & ,490 & 2,042 \\
\hline
\end{tabular}

a. Dependent Variable: kepatuhan

Berdasarkan tabel di atas maka persamaan regresi berganda dalam penelitian ini adalah sebagai berikut:

$Y=2,315+0,159 X_{1}+0,258 X_{2}+0,133 X_{3}+0,22$

$2 X_{4}$

Konstanta sebesar 2,315 berarti bahwa dengan mengesampingkan pengaruh besarnya motivasi (X1), SPPT
(X2), pelaynan fiskus (X3), dan kesadaran wajib pajak (X4), maka besarnya kepatuhan membayar pajak bumi dan bangunan kan naik sebesar 2,315. Koefisien regresi variabel motivasi (X2) sebesar 0,159 berarti bahwa jika terjadi pengingkatan motivasi (X1) maka besarnya kepatuhan membayar pajak (Y) 
akan naik sebesar 0,159. Koefisien regresi variabel SPPT (X2) sebesar 0,258 berarti bahwa jika terjadi pengingkatan SPPT (X2) maka besarnya kepatuhan membayar pajak (Y) akan naik sebesar 0,258. Koefisien regresi variabel pelayanan fiskus (X3) sebesar 0,133 berarti bahwa jika terjadi pengingkatan pelayanan fiskus (X3) maka besarnya kepatuhan membayar pajak (Y) akan naik sebesar 0,133. Koefisien regresi variabel kesadaran wajib pajak (X4) sebesar 0,222 berarti bahwa jika terjadi pengingkatan SPPT (X2) maka besarnya kepatuhan membayar pajak $(\mathrm{Y})$ akan naik sebesar 0,222.

Uji Koefisien Determinasi $\left(R^{2}\right)$

Nilai $R^{2}$ yang mendekati 1 berarti variabel-variabel independen memberikan hampir semua informasi yang dibutuhkan untuk memprediksi variabel dependen.

Tabel 4.Uji Koefisien Determinasi Simultan $\left(\mathrm{R}^{2}\right)$

\begin{tabular}{lrrrrr}
\multicolumn{6}{c}{ Model Summary } \\
\hline Model & $R$ & R Square & Adjusted R Square & Estimate \\
\hline 1 & $\begin{array}{rrrr}753 \\
\text { a }\end{array}$ &, 567 &, 549 & 2,576
\end{tabular}

a.Predictors: (Constant), kesadaran, sppt, pelayanan, motivasi

Berdasarkan tabel tersebut lain yang tidak masuk dalam analisis menunjukkan bahwa nilai adjuster $R$ regresi ini.

square yang dihasilkan oleh variabelvariabel independen sebesar 0,549 yang artinya $54,9 \%$ variabel kepatuhan membayar pajak dapat dijelaskan oleh variabel independen motivasi, SPPT, pelayanan fiskus, dan kesadaran wajib pajak. Sisanya $45,1 \%$ dijelaskan variabel

\section{Hasil F}

Jika nilai signifikansi < 5\% maka Ho ditolah dan $\mathrm{H} 1$ diterima, artinya variabel motivasi, SPPT, pelayanan fiskus, dan kesadaran wajib pajak berpengaruh terhadap variabel terikat. Hasil perhitungan menggunakan SPSS dapat dilihat dari tabel berikut.

Tabel 5.Hasil Uji F

\begin{tabular}{|c|c|c|c|c|c|}
\hline \multicolumn{6}{|c|}{ ANOVA $^{a}$} \\
\hline Model & $\begin{array}{l}\text { Sum of } \\
\text { Squares }\end{array}$ & Df & $\begin{array}{l}\text { Mean } \\
\text { Square }\end{array}$ & $\mathrm{F}$ & Sig. \\
\hline 1 Regression & 809,195 & 4 & 202,299 & $\begin{array}{l}30,47 \\
8\end{array}$ &, 000 \\
\hline Residual & 617,295 & 93 & 6,638 & & \\
\hline Total & 1426,490 & 97 & & & \\
\hline
\end{tabular}


Berdasarkan tabel 5 menunjukkan bahwa nilai $F$ hitung 30,478 dengan tingkat sigifikansi 0,000 . Karena tingkat signifikansi lebih kecil dari 0,05 maka dapat dikatakan bahwa motivasi, SPPT, pelayanan fiskus, dan kesadaran wajib pajak berpengaruh secara simultan dan signifikan terhadap kepatuhan membayar pajak bumi dan bangunan.

\begin{abstract}
Uji $t$
Kriteria yang digunakan dalam menentukan uji $\mathrm{t}$ adalah apabila nilai signifikansi masing-masing variabel bebas $<0,05$ maka variabel bebas berpengaruh terhadap variabel terikat. Hasil perhitungan menggunakan SPSS dapat dilihat pada tabel berikut.
\end{abstract}

Tabel 6. Hasil Uji t

Coefficients $^{\mathrm{a}}$

\begin{tabular}{llllll}
\hline & \multicolumn{2}{l}{$\begin{array}{l}l \\
\text { Unstandardized }\end{array}$} & Standardized Coefficients & & \\
Model & Coefficients & Std. Error & Beta & T & Sig. \\
\hline 1 (Constant) & 2,315 & 2,081 & & 1,113 &, 269 \\
Motivasi &, 159 &, 068 &, 242 & 2,332 &, 022 \\
Sppt &, 258 &, 108 &, 199 & 2,391 &, 019 \\
Pelayanan &, 133 &, 051 &, 254 & 2,608 &, 011 \\
Kesadaran &, 222 &, 101 &, 214 & 2,196 &, 031 \\
\hline
\end{tabular}

a. Dependent Variable: kepatuhan

Pengujian hipotesis kedua (H2)

Hasil uji yang dilakukan terhadap variabel motivasi memiliki nialai signifikansi 0,022 < 0,05 dengan demikian dapat dinyatakan bahwa $\mathrm{H} 2$ diiterima. Artinya motivasi berpengaruh secara signifikan terhadap kepatuhan wajib pajak.

Pengujian hiptesis ketiga (H3)

Hasil uji yang dilakukan terhadap variabel SPPT memiliki nialai signifikansi $0,019<0,05$ dengan demikian dapat dinyatakan bahwa H3 diiterima. Artinya SPPT berpengaruh secara signifikan terhadap kepatuhan wajib pajak.

\section{Pengujian hiptesis keempat (H4)}

Hasil uji yang dilakukan terhadap variabel pelayanan fiskus memiliki nialai signifikansi $0,011<0,05$ dengan demikian dapat dinyatakan bahwa $\mathrm{H} 4$ diiterima. Artinya pelayana fiskus berpengaruh secara signifikan terhadap kepatuhan wajib pajak.

Pengujian hiptesis kelima (H5)

Hasil uji yang dilakukan terhadap variabel kesadaran wajib pajak memiliki nialai signifikansi $0,031<0,05$ dengan demikian dapat dinyatakan bahwa H5 diiterima. Artinya kesadaran wajib pajak berpengaruh secara signifikan terhadap kepatuhan wajib pajak.

Pengaruh Motivasi, SPPT, Pelayanan Fiskus, dan Kesadaran Wajib Pajak terhadap Kepatuhan Membayar Pajak Bumi dan Bangunan Pedesaan dan Perkotaan.

Hasil pengujian yang diperoleh dari uji statistik $F$ menunjukkan bahwa nilai signifikansi diperoleh sebesar 0,000 . Nilai tersebut menunjukkan bahwa signifikansi dibawah nilai alfa $(0,05)$ sehingga hipotesis pertama diterima. Artinya, Khasan Setiaji, Adibatun Nisak | 18 dari 69 
terdapat pengaruh positif dan signifikan antara motivasi, SPPT, pelayanan fiskus, dan kesadaran wajib pajak terhadap kepatuhan membayar pajak bumi dan bangunan P2 Desa Nolokerto secara bersama-sama (simultan). Hal ini menunjukkan bahwa semakin tinggi motivasi, semakin akurat SPPT semakin tinggi tingkat pelayanan fiskus, dan semakin tinngi tingkat kesadaran wajib pajak maka semakin tinggi pula kepatuhan membayar pajak bumi dan bangunan perdesaan dan perkotaan.

Hasil adjusted R2 menunjukkan bahwa 54,9\%variabel motivasi, SPPT, pelayanan fiskus, dan kesadaran wajib pajak. Sedangkan sisanya $45,1 \%$ dijelaskan oleh variabel lain diluar model penelitian. Secara simultan keempat variabel bebas berpengaruh terhadap variabel terikat,maka keempat variabel bebas tersebut dapat dijadikan perhatian bagi pihak aparat pajak setempat dalam rangka meningkatkan kepatuhan membayar pajak bumi dan bangunan perdesaan dan perkotaan. Hal tersebut mendukung diterimanya hipotesis pertama. Bahwa terdapat pengaruh yang positif dan signifikan anatara motivasi, SPPT, pelayanan fiskus, dan kesadaran wajib pajak terhadap kepatuhan membayar pajak bumi dan bangunan perdesaan dan perkotaan.

Safri Nurmantu dalam Rahayu (2006:110) mengatakan bahwa, "kepatuhan perpajakan dapat didefinisikan sebagai suatu keadaan dimana wajib pajak memenuhi semua kewajiban perpajakan dan melaksanakan kewajiban perpajakannya." kepatuhan merupakan perilaku yang taat hukum. Kepatuhan wajib pajak sangat erat hubungannya dengan faktor internal (motivasi dan kesadaran wajib pajak) dan faktor internal (SPPT dan pelayanan fiskus).
Secara individual hasil analisis deskriptif variabel kepatuhan membayar pajak menunjukkan bahwa secara keseluruhan rata-rata wajib pajak patuh untuk membayar pajak bumi dan bangunan termasuk dalam kategori rendah. Hal ini dibuktikan dengan perolehan skor indikator membayar pajak tepat waktu termasuk dalam kategori rendah karena dari 98 responden 69 responden membayar pajak melampaui batas pembayaran jatuh tempo yang tertera pada SPPT. Untuk indikator tepat jumlah termasuk dalam kategori tinggi karena dari 98 responden 42 responden atau $43 \%$ membayar pajak sesuai dengan jumlah yang dibebankan. Untuk indikator tidak mempunyai tunggakan pajak termasuk dalam kategori rendah karena 43 responden atau $44 \%$ responden mereka memiliki tunggakan pajak bumi dan bangunan perdesaan dan perkotaan.

Analisis deskriptif indikator dari motivasi menyatakan bahwa indikator kejujuran termasuk dalam kategori, indikator hasrat untuk membayar pajak termasuk dalam kategori rendah, indikator dorongan dari aparat pajak termasuk dalam kategori rendah. Berdasarkan penjelasan di tersebut, dapat disimpulkan bahwa motivasi membayar pajak berpengaruh positif dan signifikan terhadap kepatuhan membayar pajak. Penelitian tersebut mendukung penelitian sebelumnya yang dilakukan oleh Susi Diana yang berjudul "analisis pengaruh motivasi dan tingkat pendidikan terhadap kepatuhan membayar pajak (studi kasus pada KPP Pratama Jakarta Tananh Abang Satu) yang menyatakan bahwa motivasi berpengaruh signifikan tergadap kepatuhan membayar pajak bumi dan bangunan baik secara parsial maupun simultan. Penelitian tersebut juga selaras dengan teori yang dikemukakan oleh Danim (2012:18) bahwa jenis motivasi Khasan Setiaji, Adibatun Nisak | 19 dari 69 
diantaranya adalah motivasi internal atau motivasi yang muncul dari dalam diri individu. Karena memang individu tersebut mempunya kesadaran untuk berbuat, kejujuran, hasrat untuk membayar pajak, dan motivasi dari luar atau motivasi yang muncul akibat adanya pengaruh dari luar seperti aparat pajak, lingkungan keluarga, kerja, dan teman.

Masing-masing indikator dari variable SPPT menyatakan bahwa indikator data wajib pajak pada SPPT dalam kategori sangat rendah, indikator tempat pembayaran pajak yang tertera pada SPPT rendah, tanggal jatuh tempo yang tertera pada SPPT tinggi, luas tanah yang tertera pada SPPT sangat tinggi, luas bangunan yang tertera pada SPPT tingi, NJOP atas tanah pada SPPT sangat tinggi, NJOP bangunan pada SPPT sangat tinggi. Berdasarkan penjelasan tersebut dapat disimpilkan bahwa SPPT berpengaruh positif dan terhadap kepatuhan membayar pajak. SPPT adalah surat yang digunakan oleh direktorat jenderal pajak untuk memberitahukan besarnya pajak yang terutang kepada wajib pajak (Waluyo,2002: 423). SPPT dalam penelitian ini menguji mengenai seberapa tinggi tanggapan wajib pajak tentang keakuratan data. Peranan SPPT telah mempengaruhi wajib pajak untuk patuh dalam membayar pajak bumi dan bangunan P2. Dari hasil penelitian, tanggapan masyarakat tentang data yang tertera di SPPT masih banyak yaang salah. Atau data yang tertera di SPPT kurang akurat. penetapan tanggal jatuh tempo termasuk dalam kategori baik, karena sebagian dari masyarakat tidak merasa keberatan dengan tanggal yang ditetapkan untuk membayar pajak. sedangkan untuk indikator luas tanah pada SPPT sudah sesuai dengan luas tanah yang dimiliki wajib pajak, untuk indikator luas bangunan pada SPPT juga sudah sesuai dengan dengan luas bangunan yang dimiliki wajib pajak. untuk indikator NJOP atas tanah dan bangunan juga sudah sesuai dengan perhitungan yang benar.

Penelitian ini juga mendukung penelitian yang sebelumnya yang dilakukan oleh Yusnidar, dkk yang berjudul "Pengaruh faktor-faktor yang mempengaruhi kepatuhan wajib pajak dalam melakukan pembayaran pajak bumi dan bangunan perdesaan dan perkotaan (studi pada wajib pajak PBB-P2 Kecamatan Jombang Kabupaten Jombang)." Yang menyatakan bahwa SPPT berpengaruh signifikan terhadap Kepatuhan membayar pajak baik secara simultan maupun parsial.

Analisis deskriptif variabel pelayanan fiskus menunjukkan bahwa secara keseluruhan rata-rata wajib pajak beranggapan bahwa pelayanan fiskus masuk dala kategori rendah. Hal ini dibuktikan dengan rata-rata variabel motivasi sebesar 32,69. Berdasarkan perolehan skor indikator tangibles (bukti fisik) termasuk dalam kategori rendah karena dari 98 responden 69 responden atau $48 \%$ wajib pajak menilai bahwa gedung beserta fasilitas untuk membayar pajak masih rendah. Untuk indikator realibility (kendalan) termasuk dalam kategori rendah karena dari 98 responden 58 responden atau $59 \%$ wajib pajak di Desa Nolokerto Kecamatan Kaliwungu menilai bahwa keandalan pegawai pajak atau fiskus masih rendah. Untuk indikator responsiviness (daya tangkap) termasuk dalam kategori rendah karena 54 responden atau 55\% responden mereka memandang bahwa daya tangkap petugas pajak atau fiskus dirasa kurang. Untuk indikator assurance(jaminan) termasuk dalam kategori tinggi karena 44 responden atau $45 \%$ responden percaya akan terjaminya keamanan data-data yang ada. Khasan Setiaji, Adibatun Nisak | 20 dari 69 
Hasil penelitian ini juga mendukung penelitian sebelumnya yang dilakukan oleh Agus Nurfaozi yang berjudul "Faktorfaktor yang mempengaruhi kepatuhan wajib pajak dalam membayar pajak bumi dan bangunan perdesaan dan perkotaan di Kecamatan Wanasari Kabupaten Brebes". Menunjukkan bahwa pelayanan perpajakan berpengaruh signifikan terhadap kepatuhan membayar pajak bumi dan bangunan perdesaan dan perkotaan di Kecamatan Wanasari Kabupaten Bebes baik secara simultan maupun parsial. Penelitian tersebut juga selaras dengan teori yang dikemukakan oleh parasuraman (1985) bahwa ada lima dimensi kualitas pelayanan, yaitu: tangibles, realibility, responsiveness, assurance, dan emphaty.

Variabel kesadaran wajib pajak menunjukkan bahwa secara keseluruhan rata-rata kesadaran wajib pajak dalam mendukung kepatuhan membayar pajak termasuk dalam kategori rendah. Berdasarkan analisis deskriptif masingmasing indikator dari variabel kesadaran membayar pajak menyatakan bahwa indikator sebab kultural dan historis, kurangnya informasi, adanya kebocoran pada penarikan pajak, dan suasara individu semuanya masuk dalam kategori rendah. Adanya kebocoran dalam penarikan pajak juga tergolong sangat mempengaruhi wajib pajak dalam memenuhi kewajiban pajaknya, bahwa adanya kebocoran dalam penarikan pajak akan membuat individu enggan untuk membayar pajak. Untuk indikator suasana individu seeperti belum punya uang, malas, tidak ada imbalan langsug dari pemerintah individu menilai masih rendah. Tingkat kesadaran yang dimiliki oleh wajib pajak berpengaruh terhadap kepatuhan membayar pajak. hal ini mengindikasikan bahwa budaya kurangnya kesadaran sangat berpotensi mengurangi tingkat kepatuhan. Sebagai warga negara yang baik, kewajibanya adalah memenuhi kewaajiban perpajakan. Penelitian ini juga mendukung penelitian yang sebelumnya yang dilakukan oleh Asriani Juaedi yang berjudul "pengaruh pengetahuan dan kesadaran wajib pajak bumi dan bangunan terhadap kepatuhan wajib pajak" yang menunjukkan bahwa pengetahuan dan kesadaran berpengaruh terhadap kepatuhan membayar pajak baik secara parsia maupun simultan. Penelitian ini juga selaras dengan teori yang dikemukakan oleh Tarmuji (2006:10) bahwa ada banyak hal yang menjadi penyebab mengapa tingkat kesadaran masih rendah diantarannya adalah: sebab kultural dan historis, kurangnya informasi dari pihak pajak kepada wajib pajak, adanya kebocoran pada penarikan pajak, dan suasana individu.

\section{SIMPULAN}

Pertama, Motivasi, SPPT, pelayanan fiskus, dan kesadaran wajib pajak berpengaruh positif dan signifikan terhadap kepatuhan membayar pajak bumi dan bangunan pedesaan dan perkotaan. Kedua, motivasi berpengaruh positif dan signifikan terhadap keppatuhan membayar pajak bumi dan bangunan pedesaan dan perkotaan. Ketiga, SPPT berpengaruh positif dan signifikan terhadap keppatuhan membayar pajak bumi dan bangunan P2. Keempat, pelayanan fiskus berpengaruh positif dan signifikan terhadap kepatuhan membayar pajak bumi dan bangunan pedesaan dan perkotaan. Kelima, kesadaran wajib pajak berpengaruh positif dan signifikan terhadap keppatuhan membayar pajak bumi dan bangunan pedesaan dan perkotaan. 


\section{DAFTAR PUSTAKA}

Algifari. 2015. Analisis Regresi untuk Bisnis dan Ekonomi. Edisi Ketiga. Yogyakarta: BPFE Yogyakarta

Budiono, B. 2003. Pelayanan Prima Perpajakan. Jakarta: Rineka Cipta

Danim \& Sudarman. 2012. Motivasi Kepemimpinan dan Efektivitas Kelompok. Jakarta: Rineka Cipta

Devano., S \& Siti, K.R. 2006. Perpajakan: Konsep, Teori dan Isu. Jakarta: Rineka Cipta.

Fauzi \& Agus, N. 2010. Faktor-faktor Yang Mempengaruhi Kepatuhan Wajib Pajak Dalam Membayar Pajak Bumi

Dan Bangunan Perdesaan Dan Perkotaan Di Kecamatan Wanasari Kabupaten Brebes. Skripsi. Semarang: Universitas Negeri Semmarang

Husein \& Abdul, G. 2012. Pengaruh Motivasi dan Pengetahuan Wajib Pajak terhadap Kepatuhan Wajib Pajak. Jurnal UNESA, vol 1 No.1

Prasetyo \& Jannah. 2008. Metode Penelitian Kuantitatif: Teori dan Aplikasi. Jakarta: P.T. Raja Gravindo Persada

Puspita \& Erna. 2016. Analisis Jalur Pengaruh Sosialisasi Terhadap Kepatuhan Wajib Pajak Bumi Dan Bangunan Kota Kediri Dengan Kesadaran Sebagai Variabel Intervening. Jurnal Akuntansi dan Ekonomi FE.UN PGRI Kediri, Vol. 1 No. 1

Putri \& Lukmana, R. 2015. Pengaruh Motivasi Membayar Pajak dan Tingkat Pendidikan Terhadap WPOP Pada Kantor Wilayah Direktorat Jenderal Pajak Daerah Istimewa Yogyakarta. Skripsi. Yogyakarta: Universitas Negeri Yoogyakarta

Resmi \& Siti. 2011. Perpajakan teori dan kasus edisi 6 buku 1. Jakarta: Salemba Empat
Robbins \& Srephen, D. 1992. Essential of Organizational Behavior. Terjemahan Sartika dan Halida. Jakarta: Erlangga

Rahmayanty \& Nina. 2013. Manajemen Pelayanan Prima. Yoyakarta: Graha IImu.

Riono. 2011. Pengaruh pendidikan dan pendapatan terhadap kesadaran masyarakat dalam membayar pajak bumi dan bangunan di Desa Wonomkeling Kecamatan Jatiyoso Kabupaten Karanganyar tahun 2011. Proposal. Surakarta: Universitas Muhammadiyah Surakarta

Samudra \& Azhari, A. 1995. Perpajakan di Indonesia (Keuangan, pajak, dan retribusi). Jakarta: Gramedia Pustaka Utama

Sugiyono. 2015. Metode penelitian pendidikan pendekatan kuantitatif, kualitatif, dan R\&D. Bandung: Alfa Beta

Suharyadi \& Purwanto. 2009. Statistika Untuk Ekonomi dan Keuangan Modern. Jakarta Selatan: Salemba Empat

Rahayu \& Kurnia, S. 2010. Perpajakan Indonesia: Konsepdan Aspek Formal. Yogyakarta: Graha IImu

Rahmayanty \& Nina. 2013. Manajemen Pelayanan Prima.Yoyakarta: Graha IImu

Resmi \& Siti. 2011. Perpajakan teori dan kasus edisi 6 buku 1. Jakarta: Salemba Empat

Robbins, Srephen, D. 1992. Essential of Organizational Behavior. Terjemahan Sartika dan Halida. Jakarta: Erlangga

Ronia, Kessi. (2011). "Faktor-Faktor yang Mempengaruhi Kepatuhan Wajib Pajak dalam Membayar Pajak Bumi dan Bangunan (Studi Kasus pada Kecamatan Pekalongan Utara 
Kabupaten Pekalongan)". Jurnal

Jurusan Akuntansi Fakultas

Ekonomi dan Bisnis. Semarang:

Universitas Dian Nuswantoro

Tarmuji., Tarsis \& Suryarini. 2006.

Pengetahuan Perpajakan.

Semarang: UNNES PRESS

Tjahjono, Ahmad \& Wahyudi, T. 2005.

Perpajakan Indonesia Pendekatan

Soal Jawab dan Kasus (Edisi

Pertama). Jakarta : PT. Raja

Grafindo Persada

Trihendradi. 2009. Step By Step SPSS 16

Analiis Data Statistika. Yogyakarta:

CV. Andi Offset

llyas, Waluyo \& Wirawan. 2002.

Perpajakan Indonesia. Edisi

Pertama. Jakarta: Salemba Empat

Yusnidar, Sumarti, \& Prasetya. 2015.

Pengaruh Faktor-Faktor yang

Mempengaruhi Kepatuhan Wajib

Pajak Dalam Melakukan

Pembayaran Perpajakan Bumi dan

Bangunan Perdesaan dan

Perkotaan (Studi Pada Wajib Pajak

PBB-P2 Kecamatan Jombang).

jurnal JEJAK. Vol. 1, No. 1 